\title{
Article \\ Do Structures Matter in the Process of Sustainable Intensification? A Case Study of Agriculture in the European Union Countries
}

\author{
Jakub Staniszewski * (D) and Łukasz Kryszak (D)
}

check for updates

Citation: Staniszewski, J.; Kryszak, Ł. Do Structures Matter in the Process of Sustainable Intensification? A Case Study of Agriculture in the European Union Countries. Agriculture 2022, 12 334. https://doi.org/10.3390/ agriculture12030334

Academic Editor: Johannes Sauer

Received: 27 December 2021

Accepted: 24 February 2022

Published: 25 February 2022

Publisher's Note: MDPI stays neutral with regard to jurisdictional claims in published maps and institutional affiliations.

Copyright: (c) 2022 by the authors. Licensee MDPI, Basel, Switzerland. This article is an open access article distributed under the terms and conditions of the Creative Commons Attribution (CC BY) license (https:// creativecommons.org/licenses/by/ $4.0 /)$.

\author{
Department of Macroeconomics and Agricultural Economics, Poznań University of Economics and Business, \\ 61-875 Poznań, Poland; lukasz.kryszak@ue.poznan.pl \\ * Correspondence: jakub.staniszewski@ue.poznan.pl
}

\begin{abstract}
In this paper, we proposed a new approach to the sustainable intensification (SI) process in agriculture in the EU Member States. In contrast to previous studies, we measured SI on a sectoral level and emphasised its dynamic rather than static nature. On the basis of Eurostat data of 27 EU countries in the period of 2005-2018, we used the Malmquist-Luenberger index to evaluate improvement in environmentally and socially adjusted total factor productivity (TFP). In $42 \%$ of cases in our sample, we observed the SI process defined as TFP increase. Subsequently, we tested the impact of structural changes on the SI process. On the basis of the panel logit model, we conclude that, in the European Model of Agriculture, where basic environmental and social issues regarding agriculture are regulated, in order to become aligned with sustainable intensification, agricultural production should become concentrated in larger farms with less labour-intense production-units capable of investments in innovative, green technologies.
\end{abstract}

Keywords: sustainable intensification; eco-efficiency; Malmquist-Luenberger index; logit panel model; structural change

\section{Introduction}

According to the concept of sustainable intensification (SI) in agriculture, an increase in resource productivity in the sector should be achieved without harming the natural environment through the implementation of innovative production methods [1-3]. A commonly referred to example of implementing SI is conservation agriculture (CA), aimed at being popularised among smallholding farmers in developing countries by the guidebook "Save and Grow" [4]. These practices have also gained some attention in Europe, but their popularity varies according to the ecological regions of the continent, and, in general, Europe lags behind other regions in the adoption of CA [5].

In the European Union context, as an example of a "SI-friendly" practice, precision agriculture is mentioned more often. It is defined as "whole-farm management strategies using information technology, highlighting the potential improvements on production while reducing environmental impacts" [6] (p.11). In this context, the term "intensification", following Buckwell et. al. [3], can be interpreted as "more knowledge per hectare", which results in higher yields with less environmental damage. In this study, we also refer to this kind of practice instead, while it is widely believed that for investment in technologies, a proper scale of production is necessary $[7,8]$.

SI was originally defined by Pretty [9] in reference to developing countries, but nowadays it is extended to agriculture in developed countries, in particular the European Union (EU) Member States [10]. In the last decade, this concept has also gained significant political attention [11-13], as it may serve as a tool for practical implementation of the so-called European Model of Agriculture. According to this model, agriculture should be economically competitive, but it should also contribute to the socio-economic development of rural 
areas and improvement of natural environment. This balance of different goals is explicitly stated in the ongoing EU common agricultural policy (CAP) reform, as evidenced by its nine key objectives [14]. They include, among others, ensuring fair incomes for farmers and competitiveness of EU agriculture in the world market, but also taking actions towards climate change mitigation and for preservation of natural landscapes. The crucial meaning of environmental dimension of farming is now more visible than ever since the impact of human activities on climate change is unambiguous [15].

Therefore, in the EU, agricultural activity is subject to a number of regulations aimed at the greening of production and environmental protection (e.g., Nitrates Directive 91/676/ECC, Bird Directive 2009/147/EC, Habitat Directive 92/43/EEC, Good Agricultural and Environmental Conditions Directive EU/1306/2013). These regulations are also part of the European Model of Agriculture [16].

Most examples of the practical implementation of the SI principles come from the micro (farm) level, with special regard to conservation agriculture (CA) [17] and precision agriculture [6]. It is also believed that "sustainable intensification will be facilitated through on-farm innovation in a process that is fostered by knowledge sharing between actors with complementary forms of knowledge" [18]. However, in the context of the new CAP, there is also a need to evaluate whether the SI process occurs at the country level, since in the new financial perspective (2023-2027), entire countries will be evaluated. What is more, because of the way in which the CAP has been financed thus far (the result of budget negotiations between Member States), arguments based on data and results of studies representative for the whole country can be key in the evaluation and discussion of the allocation of resources.

However, the questions are how can the SI be practically evaluated at the macro scale, and what are the possible factors that can accelerate or slow down the process? Therefore, the main goal in this paper is twofold: first, to propose the holistic approach to sectoral SI measurement and evaluate whether the SI process really occurred in EU agriculture after its last great enlargement (2005-2018); and second, to study the impact of structural changes of the sector on the SI process.

This paper contributes to the existing literature in a several ways. First, an alternative approach to sustainable intensification assessment is proposed. While most of the research concentrates on static analysis, answering the question of how sustainable and efficient agricultural production is, we attempted to tackle the question of what progress is being made in this field. Second, special attention was paid to structural factors when looking for the SI process determinants. We distinguished three main structural features of agricultural production in a given country: concentration (of production factors and production itself), specialisation (in a narrow range of products), and orientation (on a specific type of production, in our case, animal production). Third, in our approach, all three dimensions of sustainability are covered, i.e., we extended the scope of SI analysis to the social dimension, described by the income gap between farmers and employees outside the agricultural sector. Fourth, the issue of SI was tackled from the social science perspective, as such studies in this field are scarce $[10,19]$.

Our research strategy consisted of three steps. First, we operationalised the concept of sustainable intensification by the means of data envelopment analysis (DEA) and directional distance functions. Secondly, the SI process in agriculture of $27 \mathrm{EU}$ Member States (including the United Kingdom but excluding Croatia) was assessed using the Malmquist-Luenberger index. Finally, the structural and other determinants of the SI process were identified using a logit panel model. Our strategy followed the studies by Gadanakis et al. [20,21], wherein the authors estimated the synthetic sustainable intensification indicator using methods of efficiency measurement. A similar approach was also used in the analysis of carbon footprint generated by livestock farms [22], cultivation of forage crops in northern Germany [23], and different types of agricultural production in Austria [24]. However, these studies focused on the cases of individual farms, whereas in this paper, processed data were representative of agriculture in a country. 
In the next part of the paper, we develop the theoretical background for the impact of structural factors on the SI process and describe in detail the data and methods used. The third section is devoted to the description and discussion of results (the SI process and its determinants), whereas the last section concludes the study and provides some recommendations for agricultural policy.

\section{Materials and Methods}

One of the main goals of this research is in assessing the impact of changes in structural factors on the SI process. The possible impact of structural features on the environmental and economic dimensions of sustainable intensification, according to the theoretical literature review, is presented in Figure 1. An example to be analysed is the impact of concentration. From an economic point of view, it is perceived positively as a factor that allows farms to benefit from the scale effects [25]. It also makes investments in new technologies and mechanisation more probable because some solutions (e.g., precise farming) require a proper scale of production to be profitable [26]. Larger farms, due to higher assets, which can be used as collateral, have also easier access to credit. As a larger client, they can also negotiate better insurance offers [25].

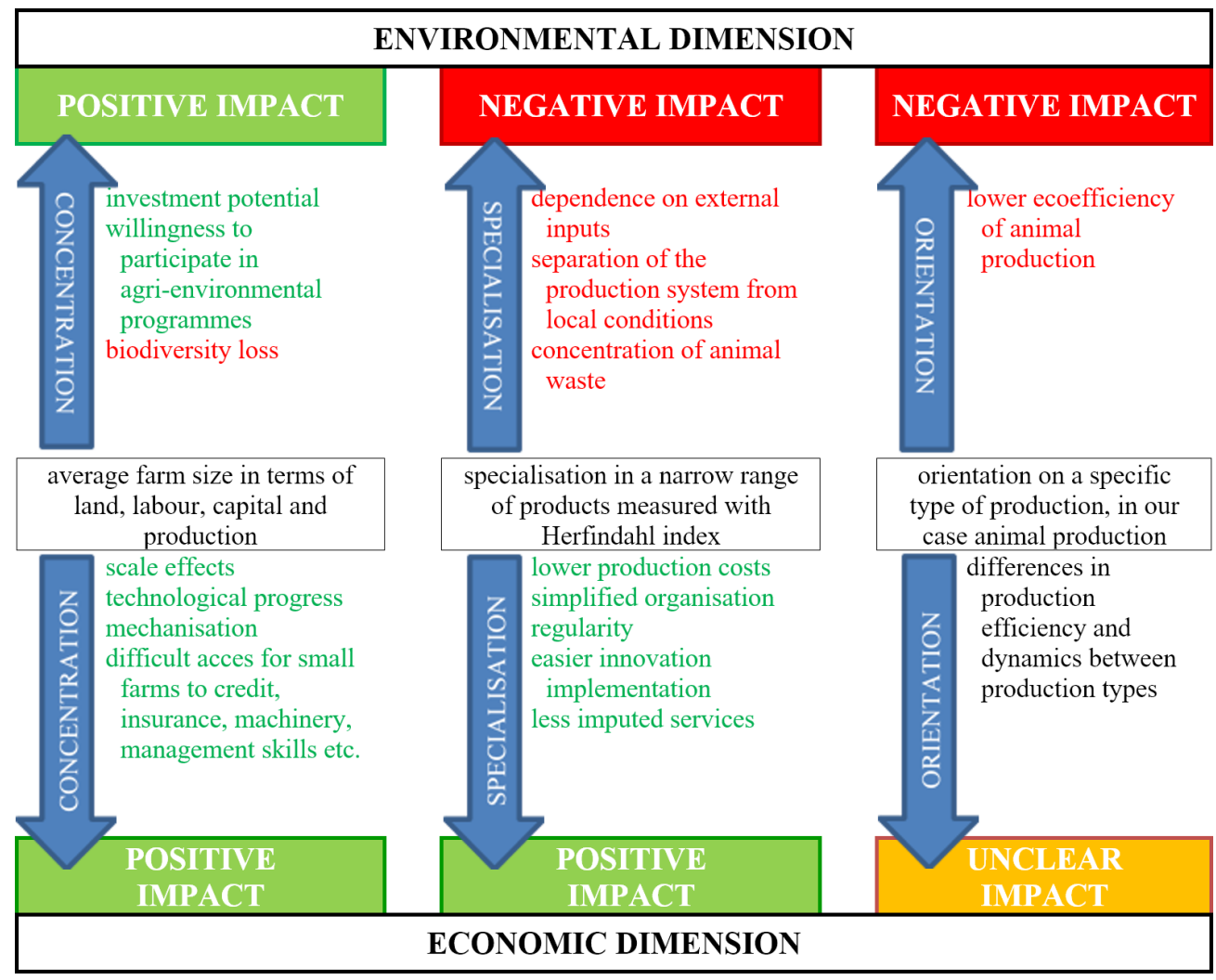

Figure 1. Theoretic impact of structural features on sustainable intensification of agriculture. Source: authors' study based on the literature review [7,25-36].

However, if one considers the environmental perspective, the positive impact is not so unambiguous. Larger farms tend to be monocultures, which limits rural biodiversity. On the other hand, they are more likely to implement agri-environmental schemes [27]. Only larger farms have enough resources to also invest in modern, environmentally friendly technologies [7]. Moreover, conservation agriculture is proving to be more popular on larger, commercial farms than on smaller farms [5]. Finally, if we sum up all abovementioned arguments, we find it to be more likely for concentration to have generally positive impact on sustainable intensification, under the assumption that the farmer follows the good agricultural and environmental condition standards, ensured to some extent in the EU by cross-compliance rules, which must be followed in order to obtain CAP support. The 
impact of specialisation and orientation can be assessed in the same way, as shown in Figure 1.

One area that has been less explored in the literature is the social dimension of sustainable intensification and its relationship with structural changes in agriculture. The most commonly repeated theory in this context is that concentration eliminates a number of farms, which decreases rural vitality [27]. One of the goals of this research was to extend the knowledge about these relations.

Therefore, we used the following structural variables as explanatory variables:

- $\quad$ specialisation, measured by the Herfindahl-Hirschman index using 14 main types of agricultural production; the index value is scaled to the range $<0,1>$ and the higher the index, the more specialised the agriculture (the share of the dominant types of production is higher);

- $\quad$ orientation towards animal production measured by the share of animal production in total agricultural production;

- $\quad$ production concentration understood as the average value of standard output calculated per one farm;

- $\quad$ land concentration measured as the average utilised agricultural area in hectares per one farm;

- labour concentration measured as the average labour input in AWU per one farm;

- capital concentration measured as the average capital input (intermediate consumption plus fixed assets depreciation) in EUR per one farm.

The robustness of the structure impact were evaluated against a set of control variables that have already been tested in previous studies. One example is technological progress, often brought up in the context of sustainable intensification [3]. We assumed that if agriculture is modernised, measured by increase in capital to labour and capital to land ratio $[37,38]$, then it would be heading toward SI. Another proxy for technological progress we used is access to the Internet in rural areas. The impact of this factor on limited innovativeness among farmers has been assessed, e.g., by Bowen and Morris [39].

We also controlled for the impact of macroeconomic environment on agriculture and the SI process following the concepts of Schiff and Valdes [40]. As a proxy of the general economic situation, we used the unemployment rate. The choice of the next control variable comes from the institutional economics. It reflects the ownership of land used for agricultural production. The theory behind this variable is that rented land will be used more efficiently because it has to generate enough production and profit to cover the additional costs of rent [41]. However, from the environmental point of view, a leaseholder may be more encouraged to exploit the land, whereas the consequences of this exploitation will be borne by the landowner [42].

Finally, following a popular strand of research [43], we decided to check the way in which common agricultural policy payments (CAP) influence the SI process. The growing relative importance of subsidies could potentially positively impact social component of the SI process, but on the other hand, a high level of subsidies may substitute for agricultural production growth, which is treated as an output in both economic and environmental aspects of SI.

Therefore, the six further control variables, used for robustness check, are:

- capital to labour ratio-measured by the sum of total intermediate consumption and fixed capital consumption calculated by one AWU (annual work unit);

- capital to land ratio-measured by the sum of total intermediate consumption and fixed capital consumption calculated by one hectare of utilised agricultural area;

- INT_RUR_-percentage of rural households with access to broadband internet connection;

- UNEMP - unemployment rate for the age group 15-74 in rural areas;

- RENTS - the ratio of rents and other real estate rental charges to be paid to total intermediate consumption;

- $\quad \mathrm{CAP}$ - value of subsidies per hectare. 
A detailed list of explanatory variables, together with data sources, is found in Table A1 in the Appendix A.

Despite the fact we have access to the data for the years 2005-2018, the results are presented for the years 2006-2018. This is because all explanatory variables mentioned above were used in index form to highlight the dynamic nature of our analysis. However, to be more informative, we present descriptive statistics for the variables both in levels and index forms in Table 1. On the basis of the presented statistics, we show that the level of specialisation in EU agriculture was not very high and it did not change much in the research period. The mean level of orientation variable- 0.47 - means that the average share of animal production in total production across EU Member States was 47\%. This measure is also rather constant; however, in some countries (e.g., Ireland), agriculture was clearly orientated towards animal production. The agrarian structure across the EU is highly diversified, as demonstrated by the minimum and maximum values of production and land concentration. For example, an average farm in Greece in 2018 produced only EUR 16,507 of output, while a farm in the Netherlands in the same period produced EUR 508,683.

Table 1. Descriptive statistics of the variables used in the panel logit model.

\begin{tabular}{|c|c|c|c|c|c|c|c|c|c|c|}
\hline \multirow{2}{*}{ Variable } & \multicolumn{5}{|c|}{ Indices } & \multicolumn{5}{|c|}{ Levels } \\
\hline & $\mathbf{N}$ & AVG & SD & Min & Max & $\mathbf{N}$ & AVG & SD & Min & Max \\
\hline Specialisation (0 to 1$)$ & 351 & 1.00 & 0.07 & 0.78 & 1.29 & 378 & 0.14 & 0.03 & 0.10 & 0.23 \\
\hline Orientation $(0$ to 1$)$ & 351 & 1.00 & 0.07 & 0.76 & 1.32 & 378 & 0.47 & 0.11 & 0.22 & 0.77 \\
\hline Prod. concentration (in EUR thous.) & 345 & 1.02 & 0.10 & 0.70 & 1.51 & 372 & 85.96 & 90.74 & 7.74 & 510.24 \\
\hline Land concentration (in hectares) & 345 & 1.01 & 0.07 & 0.70 & 1.47 & 372 & 42.70 & 37.94 & 1.69 & 227.93 \\
\hline Labour concentration (in AWU) & 345 & 0.99 & 0.08 & 0.65 & 1.45 & 372 & 1.72 & 1.12 & 0.50 & 8.01 \\
\hline $\begin{array}{l}\text { Capital concentration } \\
\text { (in EUR thous.) }\end{array}$ & 345 & 1.02 & 0.09 & 0.50 & 1.51 & 372 & 73.44 & 78.26 & 6.38 & 438.52 \\
\hline $\begin{array}{l}\text { Capital to labour ratio } \\
\text { (in EUR thous.) }\end{array}$ & 351 & 1.03 & 0.08 & 0.40 & 1.61 & 378 & 41.73 & 37.31 & 4.11 & 160.65 \\
\hline Capital to land ratio (in EUR thous.) & 351 & 1.01 & 0.05 & 0.58 & 1.21 & 378 & 2.06 & 2.14 & 0.41 & 10.96 \\
\hline INT_RUR (\%) & 348 & 1.24 & 0.51 & 0.74 & 6.00 & 378 & 55.66 & 25.68 & 0.00 & 98.00 \\
\hline UNEMP_RUR (\%) & 351 & 1.00 & 0.22 & 0.63 & 2.51 & 378 & 8.53 & 4.72 & 2.10 & 28.70 \\
\hline RENTS $(\%)$ & 351 & 1.03 & 0.14 & 0.46 & 2.01 & 378 & 4.64 & 3.25 & 0.38 & 24.60 \\
\hline CAP (in EUR per hectare) & 351 & 1.10 & 0.52 & 0.21 & 7.51 & 378 & 318 & 296 & 14 & 2446 \\
\hline
\end{tabular}

Legend: N—sample size, AVG—-mean, SD—standard deviation, Min—minimum value, Max-maximum value. Source: the authors' study based on Eurostat data.

When it comes to land concentration, of note are Malta, with average farm size in 2018 equal to 1.99 ha and the United Kingdom, where an average farm operated on 121.6 ha in 2018, or Czechia, with an average farm in 2005 being 228 ha. In terms of the size dynamics, one may notice clear differences among MS; however, on average, the economic size of a farm and its area were found to be increasing. Huge differences in capital saturation further indicate that agriculture in the EU is highly diverse. When it comes to labour, employment in agriculture was found to be slightly decreasing EU-wide. On average, 1.72 people are fully employed per farm (including the farm operator), but on large farms, such as in Czechia or Slovakia, more people are employed - up to eight people in Slovakia in 2005.

In the years 2006-2018, rural areas in the EU experienced a rapid growth in access to internet connection. In 2006 , less than $10 \%$ of rural household in some countries were able to use the Internet, while in 2018, it was more than $50 \%$ in every MS and more than 90\% in Malta, Finland, Luxembourg, the Netherlands, and the United Kingdom. Rural unemployment rate was relatively stable, but it was found to differ substantially between countries. One may also notice the important role of subsidies under CAP in EU agriculture. The average amount of payments per hectare was EUR 318, and it grew by $10 \%$ per year, but there were still clear disparities found between some newer and older MS. Rental 
payments are not a very notable expense category-the average ratio of rental payments to intermediate consumption was only $4.64 \%$.

An important research task of the paper was to also measure the process of sustainable intensification. To do so, we required proper measures of both intensity and sustainability, but ideally, they should be covered by one comprehensive indicator. The authors of a report prepared by the Rural Investment Support for Europe (RISE) identified a specific paradox concerning these issues. Intensity is well defined and easily measurable in the context of agriculture since it can be understood as a ratio of specific inputs (or obtained outputs) per hectare. However, the concept is universally criticised as the path of development, while sustainability is not sufficiently defined or measured, yet it is generally supported [3].

The concept of sustainable intensification combines the characteristics of both components. The operationalisation strategy proposed in this paper is a synthesis of "quantitative" research methods with a "qualitative" understanding of the world, which is the essence of the paradigm of sustainable agricultural development. We used quantitative methods for estimating the efficiency and total factor productivity of resources, on the basis of data on economic, social, and environmental inputs and effects of agricultural production. Our approach emerged from the trend of environmentally adjusted efficiency research and represents a new approach to the problem of creating a synthetic measure of development.

The SI indicator was calculated with the use of the Malmquist-Luenberger productivity index based on data envelopment analysis (DEA) with directional distance function introduced by Chung et al. [44] and employed in agriculture analysis, e.g., by Piot-Lepetit and Moing [45] for the pork sector in France, in the analysis of dairy farms in Ireland [46], by Majiwa et al. [47] in the analysis of the agricultural sector of Sub-Saharan countries, and by Falavigna et al. [48] in the analysis of crop farming in Italian regions. Further, Vlontzos et al. [49] applied directional distance functions of similar attributes to assess if the theory of environmental Kuznets curve is adequate for the agricultural sector in EU Members States.

Following Chung et al. [44], we were able to assume that production of good outputs (agricultural products) is accompanied by undesirable, bad by-products (greenhouse gases, ammonia emission, etc.), for which reduction is "costly" (weak disposability). This cost is either lower production of good outputs or higher usage of inputs to "clean up". In a formal way, these assumptions can be written as

$$
\begin{gathered}
P(x)=\{(y, b): x \text { can produce }(y, b)\} \\
(y, b) \in P(x) \text { and } 0 \leq \theta \leq 1 \text { imply }(\theta y, \theta b) \in P(x) \\
(y, b) \in P(x) \text { and } y^{\prime} \leq y \text { imply }\left(y^{\prime}, b\right) \in P(x) \\
\text { if }(y, b) \in P(x) \text { and } b=0 \text { then } y=0
\end{gathered}
$$

where $x \in \mathbb{R}_{+}^{M}$ are inputs; $y \in \mathbb{R}_{+}^{N}$ is a vector of good outputs; $b \in \mathbb{R}_{+}^{I}$ is a vector of bad outputs; and $P(x)$ is technology, represented by an output set. In (2), we impose that reduction in bad outputs is feasible only if good outputs are simultaneously reduced, given a fixed level of inputs. In (3), we assume that the desirable outputs are freely disposable. In (4), we show that the good outputs are "null-joint" with the bad outputs if the only way to produce no bad outputs is to produce zero good outputs.

Implementation of the abovementioned method is possible using directional output distance function that seeks to simultaneously increase good outputs and decrease bad outputs:

$$
\vec{D}_{o}(x, y, b ; g)=\sup \{\beta:(y, b)+\beta g \in P(x)\}
$$

where $g$ is a vector according to which outputs are scaled. In this paper, we followed the original assumption by Chung et al. [44] about change in outputs proportional to their initial value, which means $g=(y,-b)$. This assumption is commonly followed and accepted in 
the most applications where the purpose of the study is productivity measurement, not environmental regulation impact assessment [50].

Directional output distance function is used to calculate the Malmquist-Luenberger environmentally adjusted productivity index, according to the following formula:

$$
\mathrm{ML}_{t}^{t+1}=\sqrt{\frac{\left(1+\overrightarrow{D_{o}^{t}}\left(x^{t}, y^{t}, b^{t} ; y^{t},-b^{t}\right)\right)}{\left(1+\overrightarrow{D_{o}^{t}}\left(x^{t+1}, y^{t+1}, b^{t+1} ; y^{t+1},-b^{t+1}\right)\right)} \times \frac{\left(1+\overrightarrow{D_{o}^{t+1}}\left(x^{t}, y^{t}, b^{t} ; y^{t},-b^{t}\right)\right)}{\left(1+\overrightarrow{D_{o}^{t+1}}\left(x^{t+1}, y^{t+1}, b^{t+1} ; y^{t+1},-b^{t+1}\right)\right)}}
$$

An advantage of the index is the fact that it does not require information about input and output prices, which are unavailable in the case of non-marketable, bad outputs. However, according to O'Donnell [51], the Malmquist index, and therefore also the ML index, is not multiplicatively complete, causing a bias in the comparisons of the results between periods and objects. However, in this application, we are interested in changes of certain country in years, in the context that parallel structural changes and multiplicative completeness of the index is not necessary there.

Directional output distance functions are calculated using linear programming. As an example, we present one of four problems necessary to solve to obtain the ML index:

$$
\begin{gathered}
\quad \vec{D}_{o}^{t}\left(x^{t, k^{\prime}}, y^{t, k^{\prime}}, b^{t, k^{\prime}} ; y^{t, k^{\prime}},-b^{t, k^{\prime}}\right)=\max \beta \\
\text { s.t. } \sum_{k=1}^{K} z_{k} y_{k^{\prime} m}^{t} \geq(1+\beta) y_{k^{\prime} m^{\prime}}^{t} m=1, \ldots, M \\
\sum_{k=1}^{K} z_{k} b_{k t}^{t}=(1-\beta) b_{k^{\prime} t^{\prime}}^{t} i=1, \ldots, I \\
\sum_{k=1}^{K} z_{k} x_{k n}^{t} \leq(1-\beta) x_{k^{\prime} n^{\prime}}^{t}, n=1, \ldots, M \\
z_{k} \geq 0, k=1, \ldots, K
\end{gathered}
$$

The inequalities for inputs and good outputs in (7) make them freely disposable. Equalities for bad outputs make them weakly disposable. The non-negativity constraint on the intensity variables $z_{k}$ depicts the assumption of constant returns to scale (CRS). This assumption relating to the production technology in most cases is imposed when using an aggregate of different countries, since capturing the difference in scale becomes irrelevant [52]. Thus, since the countries' endowments such as the land size, population, and the available natural resources remain as given, they cannot be deciding factors [47].

All the calculations concerning the ML index, in particular directional output distance functions, have been conducted in R, using package "nonparaeff".

The abovementioned method was applied to evaluate sustainable intensification (SI) process. In our research strategy, following suggestions of Buckwell et al. [3], we measured the SI process with TFP change, which included economic, environmental, and social components of SI. Regarding economic dimensions of the SI process, agricultural output at constant prices was used as an output measure. Inputs were total labour force (in annual work units); land (total utilised agricultural area in hectares); and capital, understood as a sum of total intermediate consumption and fixed capital consumption, following Petrick and Kloss [53].

The environmental aspect is included by introducing bad outputs. These were greenhouse gases emission from agriculture in $\mathrm{CO}_{2}$ equivalent, ammonia emission from agriculture, and consumption of inorganic fertilisers per hectare of arable land. We are aware that this set of bad outputs is incomplete as long as it is lacking the variables describing impact of agriculture on biodiversity, animal welfare, water resources, and soil health. However, our research is limited here by data availability for a longer time period. Some research of interconnections between biodiversity and sustainable intensification that is complementary to ours has been conducted by Omer et al. [54] and Schaub et al. [55]. 
As stated in in the Introduction, an important innovation offered by this study is the inclusion of the third aspect of sustainability, namely, the social dimension, into SI analysis. It is widely accepted as a part of sustainability, but it is not clearly defined [56]. However, existing approaches focus, inter alia, on social capital and inclusion, equity, poverty, and development level [56-58]. The most basic category related to these issues is the level of income. This should be, however, assessed not only in absolute terms, but rather in relative values. We assumed that good social output of agricultural production is income parity. The higher the ratio of agricultural income (i.e., income calculated per one person employed in agriculture full time) to incomes earned by employees in the total economy, the more socially sustainable the farming sector.

This formulation corresponds to the concept of relative income deprivation [59]. The main idea of this approach is that social groups (farmers and agricultural workers in this case) compare their situation to other socio-economic groups, and thus they may feel relatively poor, even if they are quite rich in absolute terms. Keeping in mind that agricultural incomes are usually lower than in other sectors in most of the EU countries [60], the problem of relative deprivation is of a great importance from social and political perspectives. There are many possible measures of agricultural income that may be employed when using Eurostat data. In this paper, we used net value added increase by subsidies, as this measure seems to be the closest concept to gross wages and salaries in the total economy. "Entrepreneurial income" would exclude value generated by hired workers and could only be calculated per farm owner and their family. To calculate the value of social dimension of SI, we used the following formula:

$$
\frac{\mathrm{NVA}+\text { subsidies/total_labour_force_input) }}{\text { Wages and salaries/Employees }}
$$

where NVA is net value added in basic prices and subsidies is other subsidies on production.

To sum up, in our sustainable intensification assessment model, we included three inputs, two good outputs, and three bad outputs. This model is our most complex version of an environmentally adjusted efficiency measure [61]. We also propose three auxiliary indicators-TFP index for the economic dimension (standard Malmquist index, with three economic inputs and one output), economic and social dimension (standard Malmquist index with additional good social output), and economic and environmental dimension (the Malmquist-Luenberger index with three undesirable outputs). A detailed list of used inputs and outputs, together with data sources, is included in Table A1 in the Appendix A.

The method was applied to 27 European Union Member States (including the United Kingdom but excluding Croatia) during a 14 year period between 2005 and 2018. By calculating the Malmquist index or Malmquist-Luenberger index, we obtained values for relative changes in TFP in 13 periods, which effectively provided us with a panel of 351 observations. Going further, we created a binary variable describing the SI process. For all the countries and periods when TFP index was above 1, we assumed that the SI process occurred, for the rest of the observations, where TFP decreased or remained constant, we assumed the lack of SI. The justification for this approach came from the works of Simar and Wilson [62] and Ramalho et al. [63], who criticised the use of OLS or Tobit regression in the second-stage DEA efficiency analysis.

Therefore, in the second step, we proposed the search for the determinants of sustainable intensification using a logit panel model, with SI as a binary dependent variable. The probability of a positive outcome was assumed to be determined by the cumulative logistic distribution function. The model we used is a version of a logit model designed for panel data that fits the following formula via maximum likelihood:

$$
\operatorname{Pr}\left(y_{i t} \neq 0 \mid X_{i t}\right)=P\left(X_{i t} \beta+v_{i}\right)
$$

where

$i=1, \ldots, \mathrm{n}$ are countries; 
$t=1, \ldots, \mathrm{n}$ are periods;

$X_{i t} \beta$ is a vector of independent variables;

$v_{i}$ is i.i.d, $N\left(0, \sigma_{v}^{2}\right)$ and $P(z)=\{1+\exp (-z)\}^{-1}$.

A panel logit random-effect model may be sensitive to the number of integration points used in the estimation. Models in which results differ substantially when using a different number of quadrature points should not be interpreted. To check the sensitivity of our results, we tested models with 8,12 , and 16 quadrature points, finding no significant differences in the results.

\section{Results and Discussion}

First, we briefly present the results of the SI process assessment (Figure 2). These results are demonstrated in two ways. First, as a geometric average of the MalmquistLuenberger TFP index (bar chart), which provides information about the intensity of the SI process. Second, as a number of periods when SI occurred (dot chart), which offers information about the process' stability. Therefore, the two approaches are complementary.

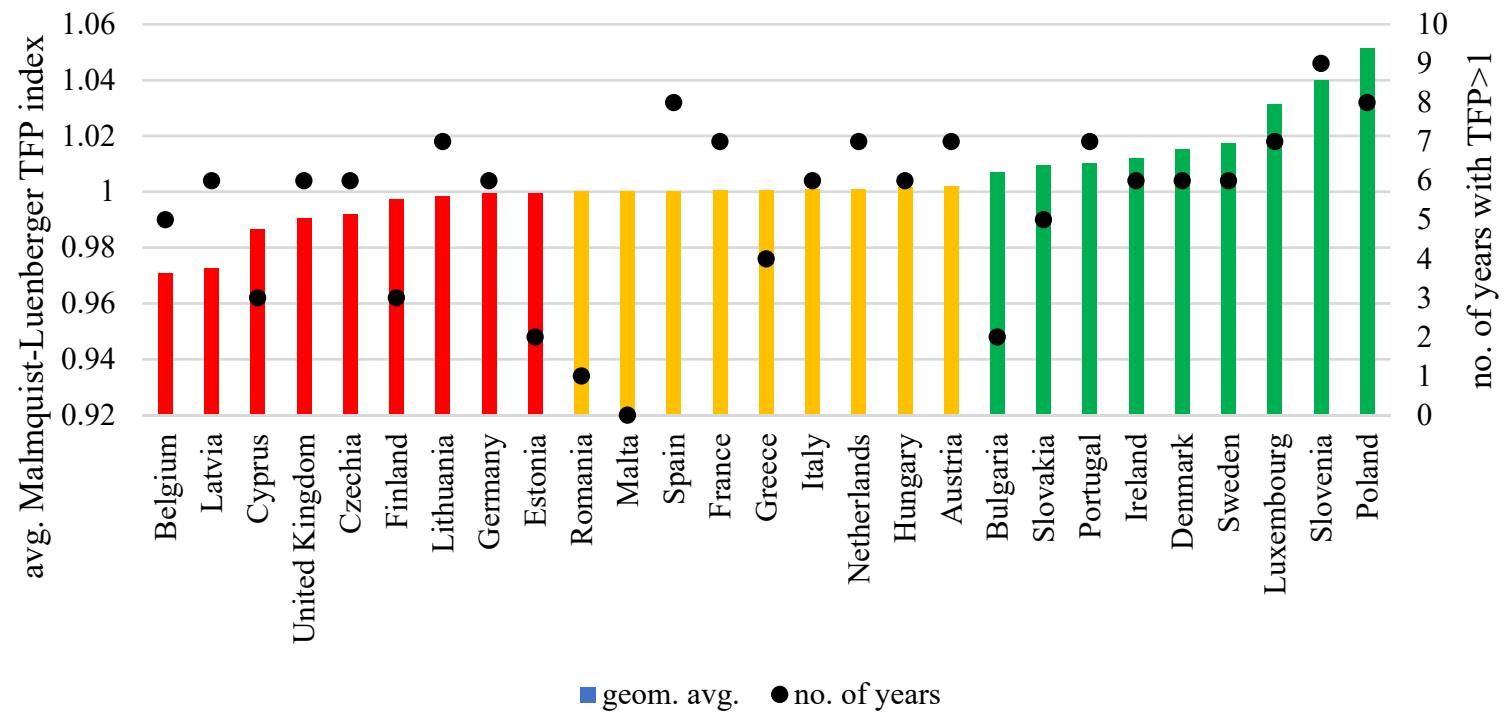

Figure 2. Average progress toward sustainable intensification in EU countries in the years 2006-2018. Source: the authors' study based on the Malmquist TFP index and Eurostat data.

Three groups of countries could be distinguished on the basis of the average. The first one, represented by green bars in Figure 2, consists of countries where improvement was the highest. Among them, Poland, Slovenia, and Luxembourg were the top three. Among the "green group", Bulgaria was an interesting case, wherein positive change was mostly driven by a two year period $(2015,2017)$ when the TFP index was far above 1 . For the rest of the studied period, it was equal to or slightly lower than 1 . For the rest of the countries in this group, improvement was relatively stable over time.

The second group, illustrated with yellow bars, consisted of countries with TFP values very close to 1 . It signified neither much improvement, nor decline. Among them, Malta and Romania were interesting cases, wherein there was almost no change in the SI indexin almost all periods, its value was equal to 1 . It indicates the fact that in all the periods, those countries were the benchmarks for others.

The last group (red bars) included countries that declined in terms of sustainable intensification. Interestingly, these countries did achieve improvement in many periods, but severe declines in other years drove their average to values below 1 .

In Figure 3, the relations between auxiliary SI indicators are presented. In all dimensions, around $50 \%$ of observations improved. However, the results clearly show that taking into account undesirable outputs affects the results to a great extent. The performance 
indicator, where environmental variables were taken into account, differed significantly from econ and econ-soc variables, which was indicated by low Yule's Y coefficient. On the other hand, adding income gap as a social output to the economic-only model did not change its outcomes much (high Yule's Y coefficient value).

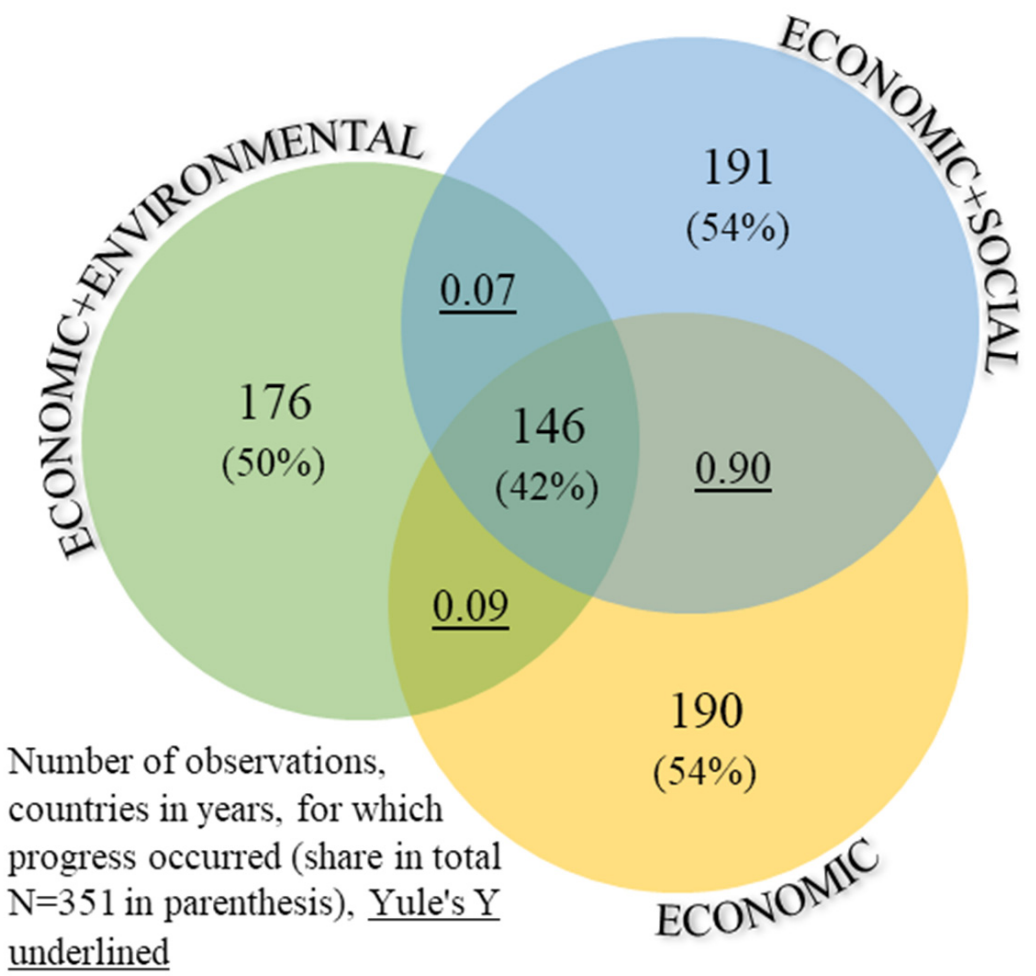

Figure 3. Breakdown of the progress toward sustainable intensification in EU countries in the years 2006-2018.

Source: the authors' study based on Malmquist TFP index and Eurostat data.

Finally, the SI process, measured with all three dimensions, occurred in $42 \%$ of observations. Our findings in this field are in line with earlier studies, which identified strong relationships between economic and social dimensions of sustainability and much weaker ones between them and the environmental aspects [64,65]. Full information about the average level and change in each country and dimension is provided in Figure A1. in Appendix A.

The main goal of this research was, however, the identification of structural factors that may have an impact on the likelihood that the SI process occurs. In Table 2, we provide the results of the panel logit model estimation. In the first step, we tried to include our main variables of interest, i.e., structural factors. It turned out that dynamics of orientation towards animal production, as well as production and labour concentration, had a significant and stable impact on the logarithm of chance that the SI process occurs, even after a set of control variables was added.

In the case of orientation towards animal production, a positive impact was identified. Such a result can be surprising, taking into account the fact that animal production is particularly resource-consuming and polluting [36]. However, this type of production generates higher output value than crop production. Thus, good outputs may outweigh bad outputs, and that is why the impact of orientation variable is positive. According to Guyomard et al. [66], properly regulated animal production may provide benefits, notably from an economic and nutritional point of view, and some livestock systems, notably grass-based systems, may also offer positive climatic and environmental effects. 
Table 2. Results of estimations (dependent variable is the SI process: 1-SI occurred, 0-SI did not occur).

\begin{tabular}{|c|c|c|c|c|c|c|c|}
\hline VARIABLE & (1) & (2) & (3) & (4) & (5) & (6) & (7) \\
\hline Specialisation & $\begin{array}{l}-1.821 \\
(1.894)\end{array}$ & & $\begin{array}{l}-1.972 \\
(1.912)\end{array}$ & $\begin{array}{l}-1.794 \\
(1.902)\end{array}$ & $\begin{array}{l}-1.836 \\
(1.897)\end{array}$ & $\begin{array}{l}-1.740 \\
(1.903)\end{array}$ & $\begin{array}{l}-1.934 \\
(1.931)\end{array}$ \\
\hline Orientation & $\begin{array}{c}9.498^{* * *} \\
(2.219)\end{array}$ & & $\begin{array}{c}9.605^{* * *} \\
(2.241)\end{array}$ & $\begin{array}{c}9.304^{* * *} \\
(2.221)\end{array}$ & $\begin{array}{c}9.517^{* * *} \\
(2.221)\end{array}$ & $\begin{array}{c}9.465^{* * *} \\
(2.221)\end{array}$ & $\begin{array}{c}9.362^{* * *} \\
(2.242)\end{array}$ \\
\hline Prod. concentration & $\begin{array}{c}10.170 * * * \\
(2.476)\end{array}$ & & $\begin{array}{c}10.609 * * * \\
(2.540)\end{array}$ & $\begin{array}{c}10.200 * * * \\
(2.488)\end{array}$ & $\begin{array}{c}10.121 * * * \\
(2.487)\end{array}$ & $\begin{array}{c}10.223^{* * *} \\
(2.484)\end{array}$ & $\begin{array}{c}10.649 * * * \\
(2.566)\end{array}$ \\
\hline Land concentration & $\begin{array}{l}-3.908 \\
(3.399)\end{array}$ & & $\begin{array}{l}-10.786 \\
(27.351)\end{array}$ & $\begin{array}{l}-3.611 \\
(3.444)\end{array}$ & $\begin{array}{l}-3.828 \\
(3.421)\end{array}$ & $\begin{array}{l}-3.772 \\
(3.414)\end{array}$ & $\begin{array}{l}-10.206 \\
(28.180)\end{array}$ \\
\hline Labour concentration & $\begin{array}{c}-4.871^{* *} \\
(2.294)\end{array}$ & & $\begin{array}{c}-17.843 \text { * } \\
(10.126)\end{array}$ & $\begin{array}{c}-4.943^{* *} \\
(2.300)\end{array}$ & $\begin{array}{c}-4.881^{* *} \\
(2.292)\end{array}$ & $\begin{array}{c}-5.015^{* *} \\
(2.318)\end{array}$ & $\begin{array}{c}-18.979 * \\
(10.354)\end{array}$ \\
\hline Capital concentration & $\begin{array}{l}-0.981 \\
(2.864)\end{array}$ & & $\begin{array}{c}18.030 \\
(30.834)\end{array}$ & $\begin{array}{l}-1.202 \\
(2.889)\end{array}$ & $\begin{array}{l}-1.012 \\
(2.866)\end{array}$ & $\begin{array}{l}-1.014 \\
(2.871)\end{array}$ & $\begin{array}{c}18.466 \\
(31.903)\end{array}$ \\
\hline Capital/labour ratio & & $\begin{array}{c}0.245 \\
(1.750)\end{array}$ & $\begin{array}{c}-11.531 \\
(8.814)\end{array}$ & & & & $\begin{array}{c}-12.349 \\
(8.991)\end{array}$ \\
\hline Capital/land ratio & & $\begin{array}{c}0.799 \\
(2.802)\end{array}$ & $\begin{array}{c}-8.129 \\
(26.869)\end{array}$ & & & & $\begin{array}{c}-8.203 \\
(27.651)\end{array}$ \\
\hline INT_RUR & & $\begin{array}{l}-0.301 \\
(0.264)\end{array}$ & & $\begin{array}{l}-0.117 \\
(0.293)\end{array}$ & & & $\begin{array}{l}-0.197 \\
(0.303)\end{array}$ \\
\hline UNEMP_RUR & & $\begin{array}{l}-0.058 \\
(0.530)\end{array}$ & & $\begin{array}{l}-0.188 \\
(0.550)\end{array}$ & & & $\begin{array}{l}-0.206 \\
(0.557)\end{array}$ \\
\hline RENTS & & $\begin{array}{l}-0.457 \\
(0.866)\end{array}$ & & & $\begin{array}{c}-0.172 \\
(0.900)\end{array}$ & & $\begin{array}{l}-0.125 \\
(0.919)\end{array}$ \\
\hline CAP & & $\begin{array}{c}0.039 \\
(0.227)\end{array}$ & & & & $\begin{array}{c}0.111 \\
(0.237)\end{array}$ & $\begin{array}{c}0.098 \\
(0.243)\end{array}$ \\
\hline Constant & $\begin{array}{c}-8.615^{* * *} \\
(3.166)\end{array}$ & $\begin{array}{l}-0.555 \\
(2.741)\end{array}$ & $\begin{array}{c}11.503 \\
(30.131)\end{array}$ & $\begin{array}{c}-8.161^{* *} \\
(3.300)\end{array}$ & $\begin{array}{c}-8.430 * * \\
(3.307)\end{array}$ & $\begin{array}{c}-8.801^{* * *} \\
(3.200)\end{array}$ & $\begin{array}{c}13.140 \\
(31.267)\end{array}$ \\
\hline Observations & 345 & 348 & 345 & 344 & 345 & 345 & 344 \\
\hline Number of groups & 27 & 27 & 27 & 27 & 27 & 27 & 27 \\
\hline
\end{tabular}

Legend: Standard errors in brackets; ${ }^{* * *} p<0.01,{ }^{* *} p<0.05, * p<0.1$.

Source: the authors' study based on logit panel model and Eurostat data.

When it comes to concentration, we describe it using four variables, but only production and labour concentration were significant, while land and capital concentration impact were estimated as negative but insignificant in all of the specifications, which is in opposition to previously obtained results [67]. The positive impact of higher production concentration was similar to the previous statements about orientation impact. It seems that higher income and production effects offset negative environmental impact. An important role of production concentration may be expected when comparing variable dynamics for cases when SI did and did not occur (cf. Table A2). The average index of production concentration for cases when SI was noticed was 1.038, and for the rest of the cases, it was 1.015. This difference was statistically significant at $1 \%$, as demonstrated by $t$-test values.

At the same time, the impact of labour concentration was significantly negative in all specifications. It means that when the index of on-farm labour use decreases faster, the logarithm of chance that the SI process occurs is growing. The main finding from the analysis of concentration variables is that in the context of European agriculture, progress towards SI is more apparent when production becomes more intensive, which means that fewer people work on farms, but the average production is growing. This leads to the conclusion of a positive impact on the sustainable intensification of labour-saving progress and reinforces earlier observations on the role of innovation and capital-intensive technological progress.

Regarding specialisation, the results did not indicate a significant impact of this variable on the SI process. On the one hand, specialisation brings about the benefits of the comparative advantage and better improves technical efficiency and profitability of the production [25]. However, it is believed that this process has a negative impact from the environmental point of view [35]. Therefore, the impact of this variable remains ambiguous. 
For robustness check, we tested several different variables that potentially may have an impact on the SI process. The obtained results do not support the hypothesis on positive impact of technological progress measured with capital ratio to land and labour. The reason for that might be a very heterogeneous character of capital in farming. This term may stand for mineral fertiliser expenditures as well as investments in precise farming technologies. Both of these categories have a completely different impact on the SI process.

Looking for a better proxy of purely innovative technology, we used statistics for internet access in rural areas (INT_RUR). However, this variable remained insignificant as well, despite the results of earlier studies, stating clearly that the lack of decent internet connection may be an obstacle in agribusiness [39] and access to it may help to improve production efficiency [68]. However, both of the studies were based on microlevel data. Apparently, these case study-type results do not translate fully to the macro, EU-level conclusions.

The third tested control variable, unemployment rate (UNEMP), remained insignificant in all estimated models, as well as the last two control variables. This may have been due to the fact that agriculture in EU is based mostly on family labour, and because of that, the sector remains independent of the general situation on the labour market.

None of the theories backing up the impact of land rental has been confirmed by our research as long as the variable RENTS remained insignificant, which corresponds with results obtained by Bojnec and Latruffe [41], who found impact of this variable to be undetermined. The same was proven to be the case with common agricultural policy (CAP). To sum up, none of the control variables proved strong enough to make the variable relevant in our models.

\section{Discussion}

Our results on SI calculations can be compared with earlier assessments of agricultural SI in EU countries. Staniszewski [69] identified the SI process in the years 2004-2013 in Poland, Sweden, and Portugal. However, other countries, classified in this study in the "green group", did not develop in line with SI principles, according to earlier research. Czyżewski et al. [70] measured changes in agricultural environmental sustainable value. Similarly to this study, they found Ireland, Sweden, Bulgaria, Portugal, and Luxemburg among the countries which improved in the years 2007-2017. However, other results were not so much in line with ours. In both cases, this may be explained by different research periods and methods, particularly the lack of social dimension in the earlier studies. The potential for SI has been assessed by the soil resilience measure in the work of Schiefer et al. [71]. They identified Luxembourg, Slovakia, and Belgium as the most resilient countries. Work by Scherer et al. [72] found the highest potential for SI in France, Italy, and Denmark. In these two cases, the differences in results are understandable, as both studies are of a static nature and represent the ex ante approach.

The results show that large farms do not necessarily have to harm the SI process. What is more, their impact can even be beneficial. This conclusion backs the logic described by Rickard [7] that only large farms have enough resources to invest in technologies supporting SI and scale production sufficient to implement these technologies (i.e., precise farming) in an efficient way. However, "large" in this context means that a farm should have a significant production level rather than it needing to be large in terms of area. Empirical proof of the positive impact of innovations from the farm level is provided by Firbank et al. [73], by Balaine et al. [74] in the case of milk production, and from cereal farms in Czechia [75]. In the last case, the subject matter is one of the most concentrated agricultural sectors in the EU.

Some of the results on determinants of the SI process were not obvious. Specialisation, capital-labour ratio, unemployment rate, and subsidies under CAP turned out to be insignificant. It is possible that the impact of specialisation may be revealed only on lower levels of analysis (regional and farm). For example, an experiment conducted by Finn et al. [76] proved a positive impact of diversification on sustainable intensification of grassland at the farm level. This provides a rationale for further research of this phenomenon. When 
it comes to capital-labour ratio, a study from Czyżewski et al. [70] found this ratio to be significant and positive for eco-efficiency improvement. Cupo and Di Cerbo [37] found it to determine sustainable efficiency improvement. There are also some studies that found a potential impact of unemployment rate. According to Wupper et al. [77], a negative correlation between family labour share and rural unemployment was found in Germany, but this connection was spurious due to cultural differences in work ethic.

A more complex explanation relates to the impact of subsidies. According to Vasco Silva et al. [78] "subsidies and price support for producers and consumers and other institutional supports for successful collaboration between research, education and extension organizations" are key factors enabling SI in developed countries.

Other authors [79] claim that farmers in the EU have benefited from overall economic growth that has created jobs outside of agriculture, which in turn has allowed for increased farm size and associated economies of scale. This finding seems to stand in opposition to our results, where unemployment rate turned out to be insignificant in terms of SI occurrence. However, the indirect impact identified by Giller et al. [79] may be important here.

According to the review conducted by Minvel and Latruffe [43], only in $22 \%$ of cases was the impact of subsidies insignificant. However, the authors concentrated only on the relationship with economic efficiency. It is possible that environmentally adjusted efficiency is less sensitive to financial incentives. Another explanation is that CAP variables, dependent mostly on the value of direct payments, are less connected with environmental practices, whereas in the analysed period of 2006-2018, the greening process only started.

\section{Conclusions}

This paper contributes to the current state of knowledge by measuring the sustainable intensification (SI) process in the agricultural sector of EU Member States and seeking the structural determinants of this process. The novelty of this study lies in the use of dynamic, sectoral, and structural approaches. We used Eurostat data to calculate adjusted total factor productivity indices which measure the economic, eco-environmental, and socio-economic aspects of SI.

It turned out that results for an "only-economic" dimension were similar to those when social output is taken into account. However, the results changed when environmental pollution in the form of bad outputs was taken into account Our result revealed the existence of three clusters of countries that differed regarding progress towards sustainable intensification. Among countries with the highest level of the SI dynamic were new Member States, such as Poland and Slovenia, but also wealthy Scandinavian countries (Denmark, Sweden), which shows that progress in SI can be obtained in different ways.

On the basis of the results of a panel logit model, we concluded that structural changes are important factors for the SI process. In line with sustainable intensification are changes in agricultural production based on orientation on animal production and concentration in economically stronger farms (not necessarily larger in terms of utilised land area) capable of investments in innovative green technologies (i.e., precision agriculture).

Contrary to some widespread beliefs [80], intensification in agriculture may be beneficial for sustainable intensification. However, this intensification should take the form of increasing production per farm (yields) by means of innovative capital investments. Furthermore, agricultural sectors in the EU countries operate in the pro-environmental legal framework, which is a part of the European Model of Agriculture. These regulations limit the possibility of intensifying production in an unsustainable way.

It is worth noting that after 2004, structural changes in agriculture in the EU have been driven by new Member States (i.e., Poland, Czechia, Slovakia, Hungary, Bulgaria, Romania, Slovenia, Lithuania, Latvia, Estonia), where the sector had to concentrate and intensify production to remain competitive. Those changes occurred simultaneously with general economic development, and, according to our results, production concentration and labour deconcentration were beneficial for SI occurrence. 
The conclusions outlined above from the study need to be considered in the context of certain limitations of our approach, which also provide guidance for further research. First of all, we treated sustainable intensification as a certain approximation of sustainability, but we are fully aware that other approaches also exist. Perhaps the most important limitation is the nature of the data we used. For a better understanding of the sustainable intensification process, we need a long time series of data at the regional and farm levels. While this study refers to a more general discussion, problems and solutions should also be identified for each crop or supply chain in a given environment. In operational reality, the need to reconcile environmental sustainability with profitability for the farm must always be taken into account. This paper provides a useful framework for such an analysis. With more specific data, the proposed research strategy can be applied more widely, for example, to particular conditions in a given country where factors such as the location of the farm on less favoured areas plays an important role. In this context, it must be noted that a general limitation for the SI concept is that it cannot be implemented everywhere. However, according to previous research [72], in most EU Member States, there are some areas suitable for SI. Finally, the social sphere of sustainable intensification should be widely included into the analysis by means of more accurate metrics. Finally, in terms of our results, it seems particularly interesting to continue research on the interaction between the SI, agricultural structure, and innovation in agriculture.

In the search for some recommendations for common agricultural policy (CAP) redesign, on the basis of our results, we can formulate three key areas of change. First, in its present form, CAP tends to support small farms (e.g., through a small farmers scheme) and a decrease in intensity (e.g., some agri-environmental schemes), but our results suggest that when one looks not only at the environmental issues of agriculture but at the economic, social, and environmental aspects simultaneously, intensification may still be an appropriate strategy for the agricultural sector. Second, to support this process, some structural reforms could be supported through the CAP. For instance, replacing labour input with capital input, which could be induced with a more generous investment support scheme or a young farmers scheme. Another option for the support of structural change is to direct the CAP funds to countries with the greatest restructuring potential, i.e., the countries of Central and Eastern Europe. This statement is in line with the objective of convergence of direct payments, which are still, per hectare, much higher in Western Europe. Third, strong support for research and innovation in the field of agriculture is essential. In the EU, it can take a form of particular themes in the Horizon Europe programme, devoted to sustainable intensification, as well as to stronger agricultural knowledge and innovation systems which could boost dissemination of innovative technologies and good practices.

Author Contributions: Conceptualisation, J.S.; methodology, J.S.; software, J.S. and Ł.K.; validation, J.S. and Ł.K.; formal analysis, J.S. and Ł.K.; investigation, J.S. and Ł.K.; resources, J.S.; data curation, J.S. and Ł.K.; writing — original draft preparation, J.S. and Ł.K.; writing-review and editing, J.S.; visualisation, J.S.; supervision, J.S.; project administration, J.S.; funding acquisition, J.S. All authors have read and agreed to the published version of the manuscript.

Funding: This research was funded by the National Science Centre (Poland) (Dec. 2018/29/N/HS4/01799).

Institutional Review Board Statement: Not applicable.

Informed Consent Statement: Not applicable.

Data Availability Statement: This research is based on publicly available data. Details are found in Appendix A.

Conflicts of Interest: The authors declare no conflict of interest. 


\section{Appendix A}

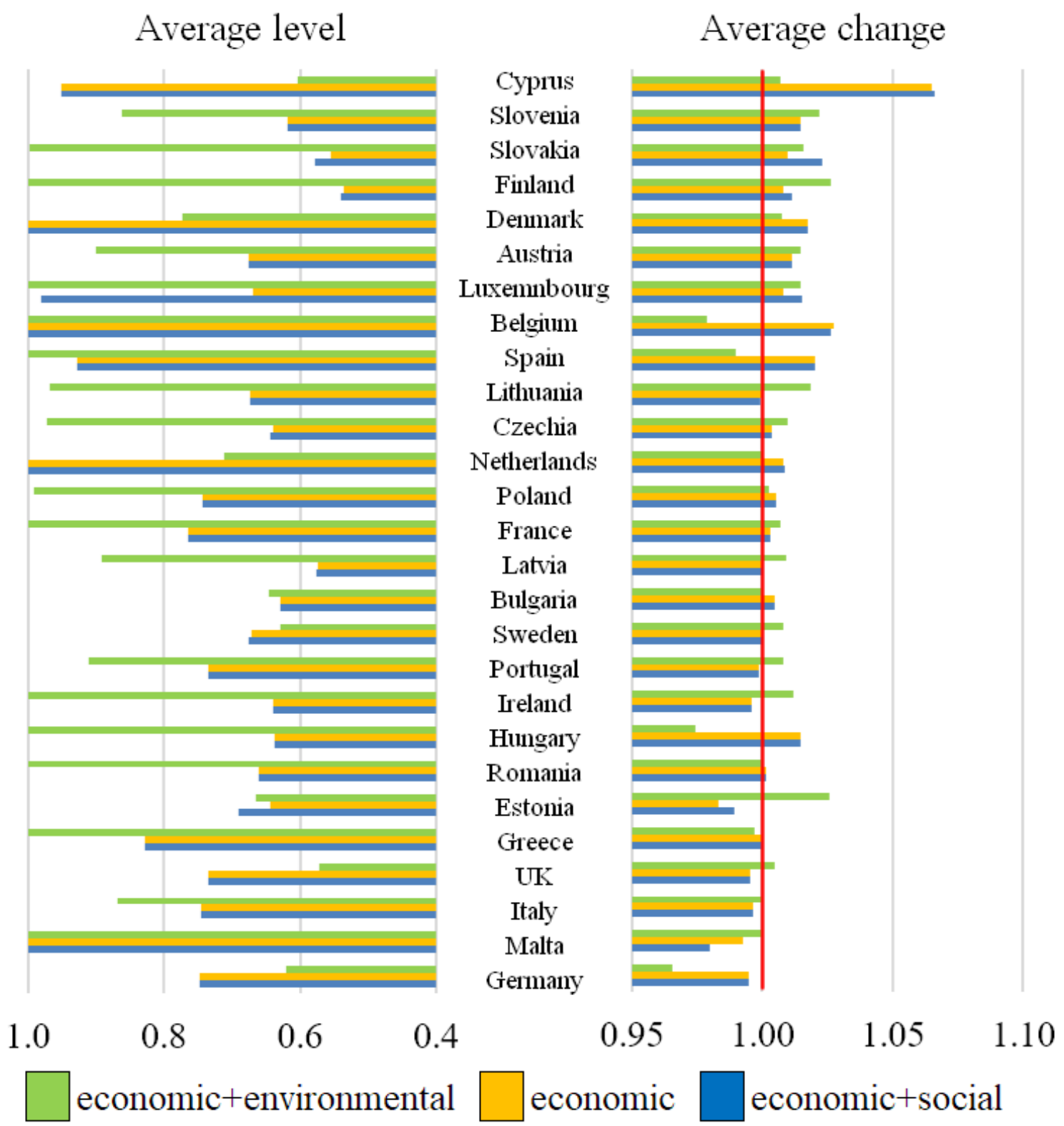

Figure A1. Dynamics and average level of sustainable intensification components in EU Member States in the years 2005-2018.

Source: the authors' study based on the Malmquist-Luenberger TFP index and Eurostat data.

Table A1. Data sources.

\begin{tabular}{|c|c|}
\hline Description & Data Source \\
\hline \multicolumn{2}{|l|}{ ECONOMIC OUTPUT } \\
\hline Agricultural goods output at basic, constant prices $(2010=100)$ & Eurostat: aact_eaa07 \\
\hline \multicolumn{2}{|l|}{$\begin{array}{ll}2+2 & \text { INPUTS }\end{array}$} \\
\hline $\begin{array}{l}\text { Sum of total intermediate consumption and fixed capital consumption at basic, constant } \\
\text { prices }(2010=100)\end{array}$ & Eurostat: aact_eaa07 \\
\hline Total labour force input in annual work units & Eurostat: aact_ali01 \\
\hline Agricultural land & FAO: 6610 \\
\hline
\end{tabular}


Table A1. Cont.

\begin{tabular}{|c|c|}
\hline Description & Data Source \\
\hline \multicolumn{2}{|l|}{ ENVIRONMENTAL OUTPUTS } \\
\hline $\begin{array}{l}\text { Greenhouse gases emission from agriculture }\left(\mathrm{CO}_{2} \text { and } \mathrm{N}_{2} \mathrm{O}, \mathrm{CH}_{4}, \mathrm{HFC}, \mathrm{PFC}, \mathrm{SF}_{6}, \mathrm{NF}_{3}\right. \\
\left.\text { in } \mathrm{CO}_{2} \text { equivalent }\right)\end{array}$ & Eurostat: env_air_gge \\
\hline Ammonia emission from agriculture & Eurostat: env_air_emis \\
\hline $\begin{array}{l}\text { N-Fertilising index: consumption of inorganic fertilisers per ha of arable land and } \\
\text { permanent crops }\end{array}$ & $\begin{array}{l}\text { Eurostat: aei_fm_usefert, } \\
\text { FAO: } 6621,6630\end{array}$ \\
\hline \multicolumn{2}{|l|}{ SOCIAL OUTPUT } \\
\hline $\begin{array}{l}\text { Net value added at basic prices, current prices } \\
\text { Other subsidises on production }\end{array}$ & Eurostat: aact_eaa01 \\
\hline Total labour force input in annual work units & Eurostat: aact_ali01 \\
\hline Employees & Eurostat: nama_10_pe \\
\hline Wages and salaries & Eurostat: nama_10_gdp \\
\hline \multicolumn{2}{|l|}{ STRUCTURAL FACTORS } \\
\hline Number of beneficiaries of all direct payments in financial years 2005-2018 & $\begin{array}{l}\text { https:/ / ec.europa.eu/info/sites/ } \\
\text { default/files/food-farming-fisheries/ } \\
\text { key_policies/documents/direct-aid- } \\
\text { indicative-figures-20xx_en.pdf } \\
\text { (accessed on 26 December 2021) }\end{array}$ \\
\hline Values of different types of agricultural production & Eurostat: aact_eaa01 \\
\hline Total labour force input in annual work units & Eurostat: aact_ali01 \\
\hline Agricultural land & FAO: 6610 \\
\hline
\end{tabular}

\section{OTHER FACTORS}

Sum of total intermediate consumption and fixed capital consumption at basic, constant prices $(2010=100)$

Total labour force input in annual work units

Unemployment rate for the age group 15-74

Households-type of connection to the internet

Rents and other real estate rental charges to be paid

Agricultural subsidies on product, on production and taxes Agricultural land
Eurostat: aact eaa07

Eurostat: aact_ali01

Eurostat: lfst_r_lfur2ganu

Eurostat: isoc_ci_it_h

Eurostat: aact_eaa01

Eurostat: aact_eaa04 FAO: 6610

Table A2. T-test values for average levels and indices of determinants of SI process.

\begin{tabular}{ccccccccc}
\hline \multirow{2}{*}{ VARIABLES } & \multicolumn{4}{c}{ Levels } & \multicolumn{3}{c}{ Indices } \\
\cline { 2 - 8 } & $\mathbf{N}$ & SI & no_SI & t_test & N & SI & no_SI & $\boldsymbol{t}$ _test \\
\hline Specialisation (0 to 1) & 351 & 0.140 & 0.142 & 0.546 & 351 & 1.002 & 1.005 & 0.371 \\
Orientation (0 to 1) & 351 & 0.470 & 0.470 & -0.050 & 351 & 0.988 & 1.007 & $\mathbf{0 . 6 0 6} * *$ \\
Prod. concentration & 347 & 96.9 & 78.7 & $-\mathbf{1 . 8 2 9} *$ & 345 & 1.038 & 1.015 & $-\mathbf{2 . 2 6} * *$ \\
Land concentration & 345 & 43.7 & 41.7 & -0.489 & 345 & 1.015 & 1.012 & -0.422 \\
Labour concentration & 347 & 1.68 & 1.72 & 0.294 & 345 & 0.996 & 0.994 & -0.216 \\
Capital concentration & 347 & 83.1 & 66.9 & -1.874 & 345 & 1.024 & 1.016 & -0.874 \\
Capital to labour ratio & 351 & 46.7 & 39.0 & $-1.881 *$ & 351 & 1.030 & 1.028 & -0.245 \\
Capital to land ratio & 351 & 2.0 & 2.1 & 0.442 & 351 & 1.009 & 1.004 & -0.765 \\
INT_RUR (\%) & 351 & 61.4 & 57.0 & $-1.719 *$ & 348 & 1.198 & 1.268 & 1.286 \\
UNEMP (\%) & 351 & 4.69 & 4.66 & -0.089 & 351 & 0.993 & 1.001 & 0.332 \\
RENTS (ratio) & 351 & 0.044 & 0.048 & -0.787 & 351 & 1.022 & 1.034 & 0.8508 \\
CAP (ratio) & 351 & 286 & 354 & $\mathbf{2 . 1 0} * *$ & 351 & 1.104 & 1.099 & -0.095 \\
\hline
\end{tabular}

${ }^{* *} p<0.05,{ }^{*} p<0.1$. Source: the authors' study based on Eurostat data.

\section{References}

1. The Royal Society. Reaping the Benefits: Science and the Sustainable Intensification of Global Agriculture; The Royal Society: London, UK, 2009.

2. Foresight. The Future of Food and Farming. Final Project Report; The Government Office for Science: London, UK, 2011.

3. Buckwell, A.; Uhre, A.N.; Williams, A.; Polakova, J.; Blum, W.; Schiefer, J.; Lair, G.J.; Heissenhuber, A.; Schie $\beta 1$, P.; Krämer, C. The Sustainable Intensification of European Agriculture; RISE Foundation: Brussels, Belgium, 2014. 
4. FAO. Save and Grow. A Policymaker's Guide to the Sustainable Intensification of Smallholder Crop Production; FAO: Rome, Italy, 2011.

5. Kertész, Á.; Madarász, B. Conservation Agriculture in Europe. Int. Soil Water Conserv. Res. 2014, 2, 91-96. [CrossRef]

6. European Parliament. Precision Agriculture: An Opportunity for EU Farmers-Potential Support with the CAP 2014-2020; European Parliament: Brussels, Belgium, 2014.

7. Rickard, S. Food security and climate change: The role of sustainable intensification, the importance of scale and the CAP. EuroChoices 2015, 14, 48-53. [CrossRef]

8. Vecchio, Y.; De Rosa, M.; Adinolfi, F.; Bartoli, L.; Masi, M. Adoption of precision farming tools: A context-related analysis. Land Use Policy 2020, 94, 104481. [CrossRef]

9. Pretty, J.N. The sustainable intensification of agriculture. Nat. Resour. Forum 1997, 21, 247-256. [CrossRef]

10. Weltin, M.; Zasada, I.; Piorr, A.; Debolini, M.; Geniaux, G.; Moreno, O.; Scherer, L.; Tudela Marco, L.; Schulp, C.J.E. Agriculture, Ecosystems and Environment Conceptualising fields of action for sustainable intensification-A systematic literature review and application to regional case studies. Agric. Ecosyst. Environ. 2018, 257, 68-80. [CrossRef]

11. European Commission. EUROPA 2020: A European Strategy for Smart, Sustainable and Inclusive Growth; European Commission: Brussels, Belgium, 2010.

12. Potočnik, J. Land Use and Natural Resources in EU Policies; Seventh Forum for the Future of Agriculture-1st April 2014; European Commission: Brussels, Belgium, 2018.

13. Hogan, P. Speech by Commissioner Phil Hogan at the Agricultural Outlook Conference-6th December 2016; European Commission: Brussels, Belgium, 2016.

14. European Commission. A Greener and Fairer CAP; European Commission: Brussels, Belgium, 2021.

15. IPCC. Climate Change 2021: The Physical Science Basis. Contribution of Working Group I to the Sixth Assessment Report of the Intergovernmental Panel on Climate Change; Masson-Delmotte, V.P., Zhai, A., Pirani, S.L., Connors, C., Péan, S., Berger, N., Caud, Y., Chen, L., Goldfarb, M.I., Gomis, M., et al., Eds.; Cambridge University Press: Cambridge, UK, 2021; in press.

16. Cardwell, M. The European Model of Agriculture; Oxford University Press: Oxford, UK, 2012.

17. Kassam, A.; Friedrich, T.; Derpsch, R. Global spread of conservation agriculture. Int. J. Environ. Stud. 2019, 76, 29-51. [CrossRef]

18. Fieldsend, A.F. Agricultural Knowledge and Innovation Systems in European Union policy discourse: Quo vadis? Stud. Agric. Econ. 2020, 122, 115-123.

19. Mouratiadou, I.; Latka, C.; van der Hilst, F.; Müller, C.; Berges, R.; Bodirsky, B.L.; Ewert, F.; Faye, B.; Heckelei, T.; Hoffmann, M.; et al. Quantifying sustainable intensification of agriculture: The contribution of metrics and modelling. Ecol. Indic. 2021, 129, 107870. [CrossRef]

20. Gadanakis, Y.; Bennett, R.; Park, J.; Areal, F.J. Evaluating the Sustainable Intensification of arable farms. J. Environ. Manag. 2015, 150, 288-298. [CrossRef]

21. Gadanakis, Y.; Bennett, R.; Park, J.; Areal, F.J. Improving productivity and water use efficiency: A case study of farms in England Agric. Water Manag. 2015, 160, 22-32. [CrossRef]

22. Hyland, J.J.; Styles, D.; Jones, D.L.; Williams, A.P. Improving livestock production efficiencies presents a major opportunity to reduce sectoral greenhouse gas emissions. Agric. Syst. 2016, 147, 123-131. [CrossRef]

23. Taube, F.; Gierus, M.; Hermann, A.; Loges, R.; Schönbach, P. Grassland and globalization challenges for north-west European grass and forage research. Grass Forage Sci. 2014, 69, 2-16. [CrossRef]

24. Grassauer, F.; Herndl, M.; Nemecek, T.; Guggenberger, T.; Fritz, C.; Steinwidder, A.; Zollitsch, W. Eco-efficiency of farms considering multiple functions of agriculture: Concept and results from Austrian farms. J. Clean. Prod. 2021, 297, 126662. [CrossRef]

25. Chavas, J. Structural change in agricultural production: Economics, technology and policy. Handb. Agric. Econ. 2001, 1, 263-285. [CrossRef]

26. Deininger, K.; Nizalov, D.; Singh, S. Are Mega-Farms the Future of Global Agriculture? Exploring the Farm Size-Productivity Relationship for Large Commercial Farms in Ukraine; Working Paper Series 49; Kyiv School of Economics and Kyiv Economics Institute: Kyiv, Ukraine, 2013.

27. Arnaud, S.; Dupraz, P. Farm Structure and Farm Characteristics-Links to Non-Commodity Outputs and Externalities. An Annotated Bibliography of the French Academic Literature; Report to the OECD; INRA: Rennes, France, 2005.

28. Lipton, M. From policy aims and small-farm characteristics to farm science needs. World Dev. 2010, 38, 1399-1412. [CrossRef]

29. Vollrath, D. Land distribution and international agricultural productivity. Am. J. Agric. Econ. 2007, 89, 202-216. [CrossRef]

30. Zegar, J.S. Struktura Polskiego Rolnictwa Rodzinnego; Instytut Ekonomiki Rolnictwa i Gospodarki Żywnościowej-Państwowy Instytut Badawczy: Warsaw, Poland, 2009.

31. Czyżewski, A.; Smędzik-Ambroży, K. Intensywne Rolnictwo w Procesach Specjalizacji i Dywersyfikacji Produkcji Rolnej: Ujęcie Regionalne i Lokalne; Wydawnictwo Naukowe PWN: Warsaw, Poland, 2013.

32. Gollin, D.; Parente, S.L.; Rogerson, R. Farm Work, Home Work and International Productivity Differences. Rev. Econ. Dyn. 2004, 7, 827-850. [CrossRef]

33. Schmitt, G. Is Structural Change Really a Source of Economic Growth? The Case of Agriculture. J. Inst. Theor. Econ. (JITE)/Z. Gesamte Staatswiss. 1990, 146, 470-499.

34. Goddard, E.; Weersink, A.; Chen, K.; Turvey, C.G. Economics of structural change in agriculture. Can. J. Agric. Econ. 1993, 41, 475-489. [CrossRef] 
35. Pretty, J.N. Regenerating Agriculture: Policies and Practice for Sustainability and Self-Reliance; Joseph Henry Press: Washington, DC, USA, 1995.

36. Davis, K.F.; Gephart, J.A.; Emery, K.A.; Leach, A.M.; Galloway, J.N.; D'Odorico, P. Meeting future food demand with current agricultural resources. Glob. Environ. Chang. 2016, 39, 125-132. [CrossRef]

37. Cupo, P.; Di Cerbo, R.A. The Determinants of Ranking in Sustainable Efficiency of Italian Farms. Riv. Studi Sulla Sosten. 2016, 2, 141-159. [CrossRef]

38. Latruffe, L.; Balcombe, K.; Davidova, S.; Zawalinska, K. Determinants of Technical Efficiency of Crop and Livestock Farms in Poland. Appl. Econ. 2004, 36, 1255-1263. [CrossRef]

39. Bowen, R.; Morris, W. The digital divide: Implications for agribusiness and entrepreneurship. Lessons from Wales. J. Rural Stud. 2019, 72, 75-84. [CrossRef]

40. Schiff, M.; Valdes, A. Agriculture and the Macroeconomy; Policy Research Working Paper 1976; The World Bank: Washington, DC, USA, 1998.

41. Bojnec, S.; Latruffe, L. Determinants of Technical Efficiency of Slovenian Farms. Post-Communist Econ. 2009, 21, 117-124. [CrossRef]

42. Leonhardt, H.; Penker, M.; Salhofer, K. Do Farmers Care about Rented Land? A Multi-Method Study on Land Tenure and Soil Conservation. Land Use Policy 2019, 82, 228-239. [CrossRef]

43. Minviel, J.J.; Latruffe, L. Effect of public subsidies on farm technical efficiency: A meta-analysis of empirical results. Appl. Econ 2017, 49, 213-226. [CrossRef]

44. Chung, Y.H.; Färe, R.; Grosskopf, S. Productivity and undesirable outputs: A directional distance function approach. J. Environ. Manag. 1997, 51, 229-240. [CrossRef]

45. Piot-Lepetit, I.; Le Moing, M. Productivity and environmental regulation: The effect of the nitrates directive in the French pig sector. Environ. Resour. Econ. 2007, 38, 433-446. [CrossRef]

46. Adenuga, A.H.; Davis, J.; Hutchinson, G.; Donnellan, T.; Patton, M. Modelling regional environmental efficiency differentials of dairy farms on the island of Ireland. Ecol. Indic. 2018, 95, 851-861. [CrossRef]

47. Majiwa, E.; Lee, B.L.; Wilson, C. Increasing agricultural productivity while reducing greenhouse gas emissions in Sub-Saharan Africa: Myth or reality? Agric. Econ. 2017, 49, 183-192. [CrossRef]

48. Falavigna, G.; Manello, A.; Pavone, S. Environmental efficiency, productivity and public funds: The case of the Italian agricultural industry. Agric. Syst. 2013, 121, 73-80. [CrossRef]

49. Vlontzos, G.; Niavis, S.; Pardalos, P. Testing for Environmental Kuznets Curve in the EU Agricultural Sector through an Eco-(in) Efficiency Index. Energies 2017, 10, 1992. [CrossRef]

50. Oh, D.H. A metafrontier approach for measuring an environmentally sensitive productivity growth index. Energy Econ. 2010, 32, 146-157. [CrossRef]

51. O'Donnell, C.J. An aggregate quantity framework for measuring and decomposing productivity change. J. Product. Anal. 2012, 38, 255-272. [CrossRef]

52. Coelli, T.J.; Rao, D.S.P. Total factor productivity growth in agriculture: A Malmquist index analysis of 93 countries, 1980-2000. Agric. Econ. 2005, 32, 115-134. [CrossRef]

53. Petrick, M.; Kloss, M. Drivers of Agricultural Capital Productivity in Selected EU Member States; Factor Markets Working Papers, No. 30; Centre for European Policy Studies: Brussels, Belgium, 2012.

54. Omer, A.; Pascual, U.; Russell, N. A theoretical model of agrobiodiversity as a supporting service for sustainable agricultural intensification. Ecol. Econ. 2010, 69, 1926-1933. [CrossRef]

55. Schaub, S.; Buchmann, N.; Lüscher, A.; Finger, R. Economic benefits from plant species diversity in intensively managed grasslands. Ecol. Econ. 2020, 168, 106488. [CrossRef]

56. Dempsey, N.; Bramley, G.; Power, S.; Brown, C. The social dimension of sustainable development: Defining urban social sustainability. Sustain. Dev. 2011, 19, 289-300. [CrossRef]

57. White, L.; Lee, G.J. Operational research and sustainable development: Tackling the social dimension. Eur. J. Oper. Res. 2009, 193, 683-692. [CrossRef]

58. Harris, J.M.; Wise, T.A.; Gallagher, K.; Goodwin, N.R. A Survey of Sustainable Development: Social and Economic Dimensions; The Global Development and Environment Institute, Island Press: Washington, DC, USA, 2013.

59. Czyżewski, B.; Poczta-Wajda, A. Effects of Policy and Market on Relative Income Deprivation of Agricultural Labour. Village Agric. 2017, 3, 53-70. [CrossRef]

60. DG Agriculture and Rural Development. Operating Subsidies (Both Direct Payments and Rural Development Except Investment Suport) European Commission: Brussels, Belgium, 2018. Available online: https://ec.europa.eu/info/sites/default/files/food-farmingfisheries/farming/documents / cap-operating-subsidies_en.pdf (accessed on 26 December 2021).

61. Dakpo, K.H.; Jeanneaux, P.; Latruffe, L. Modelling Pollution-Generating Technologies: A Numerical Comparison of Nonparametric Approaches. In Advances in Efficiency and Productivity II; Springer: Cham, The Netherlands, 2020; pp. 67-85.

62. Simar, L.; Wilson, P.W. Estimation and inference in two-stage, semi-parametric models of production processes. J. Econom. 2007, 136, 31-64. [CrossRef]

63. Ramalho, E.A.; Ramalho, J.J.; Henriques, P.D. Fractional regression models for second stage DEA efficiency analyses. J. Product. Anal. 2010, 34, 239-255. [CrossRef] 
64. Briner, S.; Huber, R.; Bebi, P.; Elkin, C.; Schmatz, D.R.; Grêt-Regamey, A. Trade-Offs between Ecosystem Services in a Mountain Region. Ecol. Soc 2013, 18, 35. [CrossRef]

65. Jaklič, T.; Juvančič, L.; Kavčič, S.; Debeljak, M. Complementarity of socio-economic and emergy evaluation of agricultural production systems: The case of Slovenian dairy sector. Ecol. Econ. 2014, 107, 469-481. [CrossRef]

66. Guyomard, H.; Bouamra-Mechemache, Z.; Chatellier, V.; Delaby, L.; Detang-Dessendre, C.; Peyraud, J.L.; Requillart, V. Why and how to regulate animal production and consumption: The case of the European Union. Animal 2021, 15, 100283. [CrossRef]

67. Grzelak, A.; Guth, M.; Matuszczak, A.; Czyżewski, B.; Brelik, A. Approaching the environmental sustainable value in agriculture: How factor endowments foster the eco-efficiency. J. Clean. Prod. 2019, 241, 118304. [CrossRef]

68. Zhu, X.; Hu, R.; Zhang, C.; Shi, G. Does Internet use improve technical efficiency? Evidence from apple production in China. Technol. Forecast. Soc. Chang. 2021, 166, 120662. [CrossRef]

69. Staniszewski, J. Attempting to measure sustainable intensification of agriculture in countries of the European Union. J. Environ. Prot. Ecol. 2018, 19, 949-957.

70. Czyżewski, B.; Matuszczak, A.; Grzelak, A.; Guth, M.; Majchrzak, A. Environmental sustainable value in agriculture revisited: How does Common Agricultural Policy contribute to eco-efficiency? Sustain. Sci. 2021, 16, 137-152. [CrossRef]

71. Schiefer, J.; Lair, G.J.; Blum, W.E.H. Indicators for the definition of land quality as a basis for the sustainable intensification of agricultural production. Int. Soil Water Conserv. Res. 2015, 3, 42-49. [CrossRef]

72. Scherer, L.A.; Verburg, P.H.; Schulp, C.J.E. Opportunities for sustainable intensification in European agriculture. Glob. Environ. Chang. 2018, 48, 43-55. [CrossRef]

73. Firbank, L.G.; Elliott, J.; Drake, B.; Cao, Y.; Gooday, R. Evidence of sustainable intensification among British farms. Agric. Ecosyst. Environ. 2013, 173, 58-65. [CrossRef]

74. Balaine, L.; Dillon, E.J.; Läpple, D.; Lynch, J. Can technology help achieve sustainable intensification? Evidence from milk recording on Irish dairy farms. Land Use Policy 2020, 92, 104437. [PubMed]

75. Čechura, L.; Žáková Kroupová, Z.; Kostlivý, V.; Lekešová, M. Productivity and Efficiency of Precision Farming: The Case of Czech Cereal Production. AGRIS On-Line Pap. Econ. Inform. 2021, 13, 15-24. [CrossRef]

76. Finn, J.A.; Kirwan, L.; Connolly, J.; Sebastia, M.T.; Helgadottir, A.; Baadshaug, O.H.; Bélanger, G.; Black, A.; Brophy, C.; Collins, R.P.; et al. Ecosystem function enhanced by combining four functional types of plant species in intensively managed grassland mixtures: A 3-year continental-scale field experiment. J. Appl. Ecol. 2013, 50, 365-375. [CrossRef]

77. Wuepper, D.; Wimmer, S.; Sauer, J. Does family farming reduce rural unemployment? Eur. Rev. Agric. Econ. 2021, 48, 315-337. [CrossRef]

78. Silva, J.V.; Reidsma, P.; Baudron, F.; Laborte, A.G.; Giller, K.E.; van Ittersum, M.K. How sustainable is sustainable intensification? Assessing yield gaps at field and farm level across the globe. Glob. Food Secur. 2021, 30, 100552.

79. Giller, K.E.; Delaune, T.; Silva, J.V.; Descheemaeker, K.; van de Ven, G.; Schut, A.G.; van Wijk, M.; Hammond, J.; Hochman, Z.; Taulya, G.; et al. The future of farming: Who will produce our food? Food Secur. 2021, 13, 1073-1099. [CrossRef]

80. Ortiz, A.M.D.; Outhwaite, C.L.; Dalin, C.; Newbold, T. Review of the interactions between biodiversity, agriculture, climate change, and international trade: Research and policy priorities. One Earth 2021, 4, 88-101. [CrossRef] 